\title{
Medicated Bar Soap Dosage Form
}

National Cancer Institute

\section{Source}

National Cancer Institute. Medicated Bar Soap Dosage Form. NCI Thesaurus. Code C91144.

A solid in the shape of a bar composed of active and inert ing redient(s) in an anionic surfactant, for cleansing. 